\title{
Taming the Tiger
}

Madero has unleashed the tiger, let's see if he can tame it.

-Porfirio Díaz

\section{I SURVEILLANCE TECHNOLOGIES AND MEXICO'S WAR ON CRIME}

Mexico's first Citizen Identity Card (CEDI) was issued on January 24, 20II, to Leslie García Rodríguez, an eleven-year-old student at the Miguel Hidalgo Elementary School in Tijuana, Mexico. To mark the event, an energetic crowd assembled outside the school-named for the revolutionary priest whose call for independence from Spain two hundred years earlier had given birth to the Mexican independence movement. One by one, students, teachers, civic activists, and public officials took to the microphone to extoll the virtues of the identity card. By housing young people's biometric identifiers-iris scans, fingerprints of all ten fingers, and a photograph—in a single card, the CEDI would "guarantee the identity" of each young person in the country and serve as a vital tool against the trafficking of minors. The city mayor noted the symbolism of launching the program in Tijuana, a major migration conduit to the United States especially susceptible to such trafficking. Secretary of the Interior Francisco Blake, the highest-ranking federal official at the event, explained that with the card, "you can be assured that the right of each of you to an identity, a name, a family, and a country is fully guaranteed. ${ }^{\mathrm{I}}$

Surveillance technologies have been growing steadily in Mexico, paralleling their spread across the world. Market dynamics here, as 
elsewhere, have helped drive the expansion. Private firms specializing in security services have exploded on the national scene. In 1989, 2 I0 companies were registered in the area of protection; by 2004, there were 2,I26. These firms generally specialize in three security sectors: information security; access to shops, homes, and factories; and vehicle reinforcement. ${ }^{2}$ But if the private sector has been driving growth in security technologies, the public sector has laid the groundwork. Various municipalities have constructed "command centers" (centros de mando) that provide surveillance of city locations through closed-circuit television (CCTV) cameras. ${ }^{3}$ Often installed to facilitate the flow of traffic, these technologies lend themselves to security operations because both emergency-response workers and the police find them essential to their work. ${ }^{4}$ Police will force their way onto traffic-monitoring systems in order to track not only criminal suspects but also street protesters, while traffic operators use the cameras to detect and report pickpockets.

As noted in the introductory chapter, surveillance technologies have featured centrally in the War on Crime launched by President Felipe Calderón. The Mérida Initiative, signed by Calderón and US president George W. Bush in October 2007 provided \$I billion for the purchase of eight Bell transport helicopters, two surveillance planes, inspection equipment such as X-ray scanners, and modernized communications and information technology. ${ }^{5}$ The Obama administration later extended the funding, set to expire in 20I0, through $20 \mathrm{I} 2$ at some $\$ 300$ million per year. ${ }^{6}$ Reflecting the increasing security cooperation between the two countries, US drones now fly over Mexico to collect data on drug cartel activities, ${ }^{7}$ while Mexican drones fly (and crash) over the United States in similar intelligence-gathering operations. ${ }^{8}$ The two countries have also established at least two fusion centers in Mexico that allow for the integration and analysis of diverse types of data related to drug trafficking. ${ }^{9}$ It was as part of this push to combat organized crime that President Calderón launched the Citizen Identity Card (CEDI), National Registry of Mobile Telephone Users (RENAUT), and Public Registry of Vehicles (REPUVE).

These three programs serve as this work's case studies, and this chapter connects them both to prevailing theories of surveillance and broader trends in Mexican history. First, while the RENAUT, CEDI, and REPUVE bear a clear resemblance to operations described by surveillance scholars elsewhere, these programs are most noteworthy for their focus on communication, identification, and mobility, collective activities central to the operation of society. Thus, rather than 
simply targeting individuals, the programs also attempt to monitor the things-phones, bodies, and cars-through which agency is exercised in society. Second, while the technologies involved in the three programs are novel, authorities' concern with controlling these dimensions of social life is not. Rather, such efforts date back to the Spanish conquest of Mexico and have served over the course of Mexican history to help "co-produce" "10 the state. Third, if authorities' efforts to administer communications, identification, and mobility have helped form the Mexican state, the appearance of the RENAUT, CEDI, and REPUVE today speaks to a crisis of governance in the country, whereby the "vibrancy" "II society has outgrown the state's ability to manage it, resulting in increased levels of insecurity. These programs featuring surveillance technologies thus represent a concerted attempt to remake the state.

\subsection{SURVEILLANCE TECHNOLOGIES, AgENCY, AND MATERIALITY}

Of the three programs examined, the National Registry of Mobile Telephone Users was the first to come to the public's attention. Created in August 2008 through an omnibus security law, the National Agreement on Security, ${ }^{\mathrm{I} 2}$ the RENAUT called for the creation of a governmental database of cell phone lines and their subscribers and required cell service providers to maintain their own databases to store subscribers' names, addresses, fingerprints, and photographs and to provide geolocalization of individual calls, all of which would aid authorities in responding to kidnappings and extortions. ${ }^{\mathrm{I} 3}$ As well, the program demanded that service providers cancel service for phones reported stolen, thereby denying kidnappers the tools-stolen phones-regularly used in their crimes. ${ }^{\text {I4 }}$

The idea for a national cell phone registry emerged following a pair of high-profile kidnapping-murders. In September 2007, nineteen-yearold Silvia Vargas, daughter of Nelson Vargas, former director of the National Sports Commission, was seized and, following failed negotiations, found dead over a year later in the basement of a Mexico City home. ${ }^{15}$ In June 2008, fourteen-year-old Fernando Martí, son of Alejandro Martí, a sports-apparel mogul, was kidnapped while being driven to school and later found dead in the trunk of an abandoned car after two months of confused negotiations. ${ }^{16}$ Alejandro Martí subsequently founded the civic group Mexico SOS (Public Security Observation 
System), which has played a prominent role in critiquing government security efforts and has worked to reform justice administration in Mexico. Increased vigilance over cell phones was an idea promoted by the organization from its founding. ${ }^{\text {I }}$

To implement the program, the Secretariat of the Interior (SEGOB) required cell users to register their phones with the RENAUT. Users could register either by sending a text message with their names and date of birth or Unique Population Registry Code (CURP), Mexico's equivalent of a national identification number, or by going to a serviceprovider center to have their data entered. ${ }^{\mathrm{I}}$ In February 2009, the government announced that cell users would have until April ıо, 2010, to register their phones or have their service cut. ${ }^{\text {I9 }}$

The Citizen Identity Card, meanwhile, was announced in July 2009. The CEDI is a 3.4-by-2.I-inch plastic card containing the following information: two photographs (one embossed using the person's CURP or national identification number), name, birth date, bar code containing the person's CURP, and double bar code containing the person's iris scans. ${ }^{20}$

The card, supporters argued, would hold multiple benefits for Mexicans. First, it would facilitate daily transactions by providing a single form of identification to replace the innumerable forms that Mexicans currently possess-birth certificate, driver's license, voter card, advanced electronic signature for tax payments, military service card, and so on. Second, it would increase people's security from identity theft and fraud by providing a more sophisticated technological basis for establishing identity. ${ }^{21}$

The legal basis for the identity card derives from reforms made in I 990 and I 992 to the country's Population Law, in which the Salinas administration, in the context of rising migration to the United States, called for the creation of a National Population Registry (RENAPO) and the distribution of Citizen Identity Cards for those registered. ${ }^{22}$ Similar to the RENAUT, participation in the CEDI program was obligatory. Mexicans would attend service centers where an array of technological devices provided by the Smartmatic Corporation ${ }^{23}$ - computer laptop with Ethernet interface, fingerprint capture device, signature capture device, iris capture device, document scanner, bar code reader, among other things-would record biometric measures and legal identity. The cards themselves would be distributed later.

The third program-the Public Registry of Vehicles-received much less attention in the media. The REPUVE possessed three 
objectives: (I) to create a centralized federal registry of all cars circulating in the country, including vehicle identification number, registration information, physical description, and the name and address of owners; (2) to attach I 8000-6C radio-frequency identification (RFID) tags to vehicles containing the unit's registration details; and (3) to install RFID readers and license plate recognition cameras at tollbooths and other transit points to verify the status of passing vehicles. ${ }^{24}$ First announced on March 3, 2008, by the head of Mexico's Secretariat of Public Security, Genaro García Luna, the technology utilized in the registry was to serve as a tool to combat crimes involving automobiles, including car thefts, kidnappings, and drug trafficking. ${ }^{25}$ Enrollment, as in the cases of the RENAUT and CEDI, was mandatory. ${ }^{26}$

President Calderón placed the first RFID sticker on the inside windshield of a Chevrolet Suburban at the Puente de Ixtla tollbooth on the Cuernavaca-Acapulco Highway outside Mexico City in June 2009. ${ }^{27}$ In the following months, several states began installing tags on their public vehicle fleets. And a few states, Zacatecas and South Baja California among them, soon extended the provision to private vehicles as well. ${ }^{28}$

At first blush, the RENAUT, CEDI, and REPUVE appear to share much in common with surveillance technologies described elsewhere. The programs involve a variety of technological devices: identification technologies such as documents, numbers, RFID stickers, and biometric registers that affix identities to people, phones, and vehicles; information technologies in the form of integrated databases that store and share these identifying data along with geographic location; imaging technologies-video cameras-that read license plates and verify identities; and monitoring technologies, including RFID readers and phone logs, that track people and their things. The function of this technological assemblage is to monitor. These are surveillance systems, then, but with a high level of sophistication. They are not mere tools-such as thermal-imaging technologies ${ }^{29}$ or crime-analysis software ${ }^{30}$ - that security agents deploy to see things that otherwise would not be seen. Rather, they are examples of the "new surveillance" ${ }^{3 \mathrm{I}}$ or "dataveillance" ${ }^{32}$ that, through the extraction and management of data about people and things, allows for constant, automated monitoring and identification across multiple physical, analog, and digital spaces.

The goal of this surveillance is to recognize and disable phones, cars, and people that carry suspect identities. In this respect, the programs share an affinity with surveillance projects described elsewhere, such as the NEXUS ${ }^{33}$ and US VISIT ${ }^{34}$ programs at the US border that seek to 
distinguish suspicious people who would harm the country from trusted global or "neoliberal citizens" who would contribute to the country's prosperity. The governmentality at work in the programs is thus similar as well. Matching Michel Foucault's description of the "double system" at work in "security," where the state deploys "great mechanisms of incentive-regulation" to ensure "the security of the natural phenomena of economic processes or processes intrinsic to population" together with "simply negative functions" to suppresses elements of disorder and illegality, these programs aim to separate out trustworthy callers from those who would use phones to extort money, trustworthy car sellers and buyers from those who would deal in stolen vehicles, and trustworthy people from those who would nab others or their identities for illicit ends. ${ }^{35}$ This is surveillance for the sake of security, then, which aspires to the "social sort" ${ }^{36}$ of citizens, phones, and cars to create a vibrant social environment secure from the specter of criminal activity. In sum, the adoption of surveillance technologies in Mexico could be read as part of a more general global shift to security governance, whereby public and private authorities adopt advanced technologies in order to sort flows of people and things and better control society. ${ }^{37}$

While such an interpretation is not wrong, a simple application of the surveillance literature, which is largely based on empirical research in the United States, Canada, and Great Britain, to the Mexican context risks overlooking other dimensions of the technologies central to understanding their adoption in Mexico and more generally. ${ }^{38}$ As a first step, for instance, we can observe that the RENAUT, CEDI, and REPUVE target fundamental aspects of social life tied to insecurity and organized crime. The national cell phone registry responds to the fact that government possesses no reliable way to track the communications of kidnappers, who use either victims' phones or units purchased on the black market to negotiate ransoms. The national identity card addresses the considerable difficulties the Mexican state has encountered in identifying persons. In early 20I3, it was reported that some fifteen thousand corpses had been encountered during the Calderón sexenio that were never identified before being buried in common graves. ${ }^{39}$ The car registry, meanwhile, is meant to tackle the mobility of crime, both the high number of auto thefts ${ }^{40}$ and the central role of automobility in the kidnappings and drug trafficking. In seeking to increase the government's control over mobile communication, personal identification, and automobility, the programs can be read as attempts to order the collective agency of society, or those practices that make collective life possible. 
The concern with monitoring communication, identifying persons, and tracking mobility is not specific to the modern Mexican state. As James Scott explains in his seminal book, Seeing Like a State, states have always sought to control these human capacities. Scott writes, "Nomads and pastoralists (such as Berbers and Bedouins), hunter-gatherers, gypsies, vagrants, homeless people, itinerants, run-away slaves, and serfs," people whose mobility and means of subsistence make it difficult to tax, "have always been a thorn in the side of states." ${ }^{4 \mathrm{I}}$ As a result, "the precolonial state was . . vitally interested in the sedentarization of its population-in the creation of permanent, fixed settlements." ${ }^{42}$ The ability to order populations, in turn, rests on "state simplification," schemes for making people's daily lives legible to the state and open to intercession. Of these schemes, the most central perhaps is "the imposition of a single, official language," which standardizes modes of communication in a given territory. ${ }^{43}$ Critical, too, are the methods by which people identify themselves. "The assigning of patronyms by family," Scott observes, "was integral to state policy promoting the status of (male) family heads, giving them legal jurisdiction over their wives, children and juniors and, not incidentally, holding them accountable for the fiscal obligations of the entire family." ${ }^{44}$

Connected to these efforts is a concern with the materiality of collective agency. Communication in contemporary society is increasingly predicated on "mobile telephony," "which requires mobile devices linked by radio frequency to a larger technological infrastructure of cell phone towers, telephone exchanges, and fiber cables. Similarly, movement in modern society is based disproportionately on "automobility," ${ }^{46}$ which requires less the capacity to move oneself than the dexterity to operate a complexly simple machine that will do so in one's place. Finally, identification is carried out not so much by naming practices as through numbers and biometric data inscribed on "national identity cards" and documents that, like a common, national language in prior ages, can meet the "need for universally acceptable tokens of identification." ${ }^{47}$

These examples illustrate the point that people's ability to partake in the tasks of collective life-communication, mobility, and selfidentification-is mediated in nearly every instance by technology. This understanding is a point of departure for science and technology studies (STS) scholars who have produced a robust collection of work evidencing how society consists of "actor networks" involving both human and nonhuman actors. ${ }^{48}$ Automobility requires both the driver and car, not to mention the enormous assemblage of people and things needed to 
train drivers, manufacture vehicles, and keep both in functioning order. In short, the capacity to communicate, move, or identify oneself is no longer inherent or exclusive to the individual person. Rather, agency in society is "distributed" across an architecture of material things that gives agency to those connected to it. ${ }^{49}$

In their focus on cell phones, motor vehicles, and human biology, the RENAUT, REPUVE, and CEDI, respectively, reveal the sensitivity of governmental authorities to the importance of materiality within collective agency. In order to get a grasp on communications in contemporary society needed to combat the kidnapping of people, in order to take hold of mobility to stop the transportation of illicit drugs and weapons, in order to account for the identification of people to investigate crime, the RENAUT, REPUVE, and CEDI target the materiality of these activities.

\subsection{COLLECTIVE AGENCY AND THE CO-PRODUCTION OF THE STATE ACROSS MEXICAN HISTORY}

While the significance of materiality to projects of social ordering has only more recently become apparent in the social sciences, political authorities have long been aware of it. Indeed, as this section emphasizes, efforts to control communication, identification, and mobility can be found throughout Mexico's history. And these efforts to capture and control agency in society have played a key role in the "co-production" of the Mexican state.

\subsection{The Conquest of the Mexica}

It is accepted today that the Spanish conquest of the Aztec empire (more accurately called the Triple Alliance of the Mexica, Texcoco, and Tlacopan peoples, or the Mexica empire, since the Mexica held the most influence in the alliance) by Hernán Cortés and his expedition of six hundred men owed primarily to the power of smallpox, which the Spanish carried with them from the European continent, and political alliances, which Cortés struck with rivals, such as the Tlaxcalteca, whom the Triple Alliance had subjugated. Without the force of disease and the vast numbers of warriors offered to the Spaniards, it is improbable that Cortés would have been able to fell the mighty Mexica empire.

But underpinning this history as well was the expedition's ability to penetrate the Mexican system of communication and mobility. 
Communication was particularly vital to the Spanish cause. The Spanish had no knowledge of the major language groups spoken in Mesoamerica-Nahuatl in the Valley of Mexico and Mayan on the Yucatán Peninsula. And this would have hampered their ability to negotiate alliances to conquer the Mexica had it not been for their chance encounter with two extraordinary historical figures-La Malinche and Gerónimo de Aguilar.

La Malinche was an indigenous woman born into a noble family but later given away to a community in Tabasco once her father died and her mother remarried. The unfortunate circumstance left her knowledgeable of both Mayan and Nahuatl dialects. When the Cortés expedition defeated the Tabascans, the Tabascan cacique, or chief, offered Cortés twenty slave women as a peace offering, a group that included La Malinche. Gerónimo de Aguilar, meanwhile, was a Spaniard who was part of an earlier expedition of the Yucatán Peninsula that had shipwrecked. Most on board were enslaved by a local indigenous group and perished either through hard labor or human sacrifice. De Aguilar escaped his captors and took refuge with another community of natives inhabiting lands near the island of Cozumel. Through his ordeal, de Aguilar learned the local Mayan dialect and thus could communicate between the Spanish and Mayans. When he learned of the arrival of the Spanish at Cozumel, de Aguilar and a group of natives raced out in canoes to meet them and the Spaniard joined Cortés's company. ${ }^{50}$ Together, Doña Marina, the name under which La Malinche was baptized, and Gerónimo de Aguilar enabled Cortés to communicate and negotiate with the native groups he encountered on the way to Tenochtitlan, the capital of the Mexica empire.

The importance of the translators was lost on neither the Spanish nor the peoples they came into contact with. Doña Marina formed such a vital part of the Spanish company that the Mexica actually referred to Cortés as Malinche, revealing how they saw Cortés and Marina as a single, unified being (fig. I). Bernal Díaz del Castillo, chronicler of the campaign, held no reservations in assessing La Malinche's contribution. "This woman was a valuable instrument to us in the conquest of New Spain. It was, through her only, under the protection of the Almighty, that many things were accomplished by us," he wrote. "Without her we never should have understood the Mexican language, and, upon the whole, have been unable to surmount many difficulties."

The Spaniards' ability to overcome the mobility of the Mexica was also central to the conquest. In obvious ways, the Spanish, with 


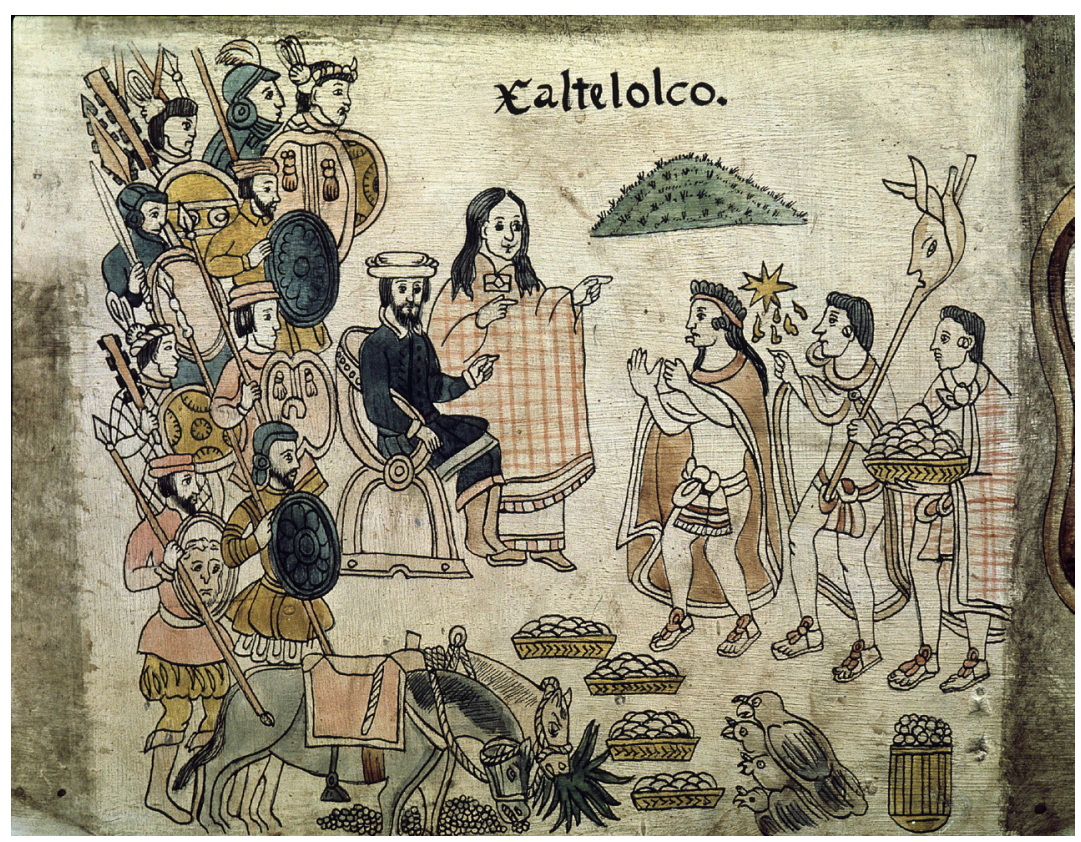

FIGURE I. Hernando Cortés, I 48 5-I 547, Spanish conquistador, with the Indian interpreter Marina, or the Malinche, and Aztecs. From copy of I632 Codex Tlaxcala, National History Museum, Mexico City. Photo by Gianni Dagli Orti/The Art Archive at Art Resource, NY.

their massive sea vessels armed with cannons and horses that could be mounted for combat, enjoyed clear advantages in terms of mobility. That said, those central components of European warcraft proved of marginal utility to Spanish attempts to conquer Tenochtitlan. Constructed on an island in Lake Texcoco, the Mexica capital was adjoined to land by three major causeways. The Spanish were famously awestruck upon first seeing the city. "When we gazed upon all this splendour at once, we scarcely knew what to think," Bernal Díaz remembered, "and we doubted whether all that we beheld was real. A series of large towns stretched themselves along the banks of the lake, out of which still larger ones rose magnificently above the waters. Innumerable crowds of canoes were plying everywhere around us; at regular distances we continually passed over new bridges, and before us lay the great city of Mexico in all its splendor." ${ }^{52}$ The aquatic location could be defended by thousands of warriors patrolling the lake with canoes. While the Tlaxcalteca and other groups allied with the Spanish had their own canoes, 
the numbers were unfavorable. The physical layout of the city thus rendered useless the Spaniards' ostensible advantage in mobility. And during Cortés's first advance on the city, the vast numbers of Mexica and allied warriors were able to stymie the Spanish.

In an attempt to change the balance of power, Cortés decided to lay siege to the city by destroying the aqueducts that brought fresh water, negotiating alliances with the other peoples residing near the lake and mounting a blockade aimed at depriving the city of provisions. To carry out the siege, Cortés ordered the construction of twelve brigantines, small fortified ships. The brigantines were constructed in Tlaxcala and outfitted with gear and weaponry from the Spanish fleet, which Cortés had disassembled to disabuse his company of any thought of abandoning the mission. Once launched on Lake Texcoco, the ships enabled Cortés to patrol the waters to prevent food and water from arriving and giving cover to Spanish and Tlaxcalan troops approaching on Tenochtitlan's causeways. With the mobility of the Mexica neutralized, Cortés was able to advance on and eventually seize their capital.

\subsubsection{Ordering Colonial Life in New Spain}

The Spanish conquest of Mexico was thus based in large measure on the ability of the invaders to seize the communications and mobility that made the Mexica and Triple Alliance dominant in the Valley of Mexico. Generally speaking, the conquistadors did not concern themselves with modes of personal identification among the peoples they

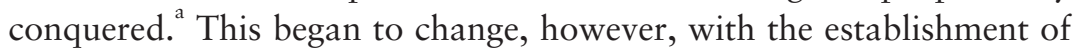
colonial order in the land the Spanish coined New Spain.

a. The Catholic Church was in a different position, however, its function in the conquest the conversion of souls. The clergy did stand alongside conquistadors when subjugating native peoples, reading the Requirement that announced Spain's divine right to conquest for the purposes of evangelization. But the salvation of souls, as per Christian tradition, also required baptism. And to complete and keep records of baptisms, the church assigned individual identities to the native population. Individuals were usually given two names, both first names, an accommodation to the fact that last names were not a convention in pre-Hispanic Mexico. The first name was almost exclusively Spanish, following the most popular saints. Second names were more varied: Spanish names (Juan Diego), Nahuatl names (Juana Quautzontecontzin), and other designations announcing social position (Doña María Xalatlauhco) or devotion (de la Cruz, "of the Cross"). Nahuatl men usually possessed more distinction in their second names than women, which reflected that they could hold local political office. Names thus not only served the administrative purposes of the church but also inscribed the unequal social order enforced by the Spanish (Horn, "Gender and Social Identity," I I9-22). 
The political economy of the Spanish empire was based on the extraction of precious metals from its colonial holdings. Internally, the colonies required agriculture and livestock to subsist. Both activities required a sizable workforce. And in New Spain, the conquered peoples would presumably provide this labor.

In subjugating the native groups of New Spain within the colonial order, the Spanish relied on existing structures of indigenous social hierarchy. The conquistadors, initially with the blessing of the Crown, established the encomienda system, a feudal structure under which vast tracts of land and the peoples living on them came into the possession of individual members of Cortés's expedition. Indigenous villages were ruled by local chiefs, caciques, who were responsible for collecting tribute from their subjects, which included forced labor in the mines. ${ }^{53}$ In political terms then, "things did not change as much as one would have thought" for the ordinary indio in Mexico, as systems of tribute and hierarchies remained the same, save for compulsory military service and human sacrifices. ${ }^{54}$

The boundaries between these two societies quickly broke down, however. The paucity of Spanish women in New Spain resulted in unions between Spanish men and indigenous women, resulting in mestizo children. ${ }^{55}$ Disease and hard labor also decimated the indigenous populations, ${ }^{56}$ which led to a labor shortage and the introduction of African slaves to the colony. ${ }^{57}$ The eventual and ongoing mixing of people "produced a tertiary, intermediate people identified as castas" in Mexico. ${ }^{58}$ Already in the 1540 , the ruling elite in New Spain identified castas as a threat to the social order, "the colony's foremost partisans of insurrection." $" 59$

In response to the perceived menace of mixed races, colonial authorities developed a caste system by which they could identify and order the evolving society. At the core of the casta system were five basic races: españoles, indios, mestizos, negros, and mulatos. ${ }^{60}$ From this emerged different combinations-zambo, for instance, which designated people who were half Indian and half African. ${ }^{61}$ Over time, more than forty categories were created, even if most lacked practical significance. ${ }^{62}$ Castas varied in terms of rights and responsibilities. Castas in the I $500 \mathrm{~s}$ were forbidden from living in indigenous villages or neighborhoods in town: "The crown in effect assigned the castas to the Spanish community." Negros and mulatos, like indios, had to pay tribute. However, they could not dress like indios or in gold jewelry, indicative of European ancestry. Nor could they hold office or bear arms. Mestizos, 
meanwhile, did not have to pay tribute. And unlike indios, who were considered gente sin razón (people without reason), essentially children who needed to be cultivated into Christian civilization, mestizos were gente de razón (people with reason). ${ }^{64, \mathrm{~b}}$

With such measures, colonial authorities sought to identify and order people in New Spain through an examination of the body. This anchoring of personal identity to the body was reinforced through technological means as well. Separate marriage registers existed for different castas. ${ }^{65}$ And pinturas de castas become a popular form of cultural expression during the eighteenth century (fig. 2). ${ }^{66}$ The paintings, which depict the different race combinations, possess a clear pedagogical function in explaining the castas and their hierarchy to the viewer. And in doing so they served to reify the largely arbitrary racial classifications that authorities sought to impose upon the people of New Spain in order to expand their political control.

While the entrenchment of Spanish rule in Mesoamerica involved controlling the material aspects of communication, such as destroying indigenous religious artifacts ${ }^{c}$ and establishing schools ${ }^{\mathrm{d}}$ to train children of the indigenous noble class, the Spanish Crown's management of mobility is more relevant to the current discussion. Gold most appealed to the Spanish, but lands to the north in and around the city of Zacatecas proved richer in silver deposits. And mines were established throughout the region. The transfer of wealth back to Spain, meanwhile, required a system of roadways that joined the mines to the colonial capital and the main seaport of Veracruz. Thus was born the Camino Real de Tierra Adentro, the Royal Road of the Interior Lands, which eventually

b. Race thus functioned differently in New Spain than in North America. If in North America "a single drop of black blood sufficed in staining people, in the Indies, a single drop of white blood precipitated a 'whitening' of people." For this reason, indios might try to escape the obligations of tribute and the political and resource limitations of village life by entering the labor markets and racial castes of the mestizaje (García Martinez, "Los años de expansión," 220).

c. Interestingly, Juan de Zumarrago, the first bishop of New Spain who was also given the political post of protector de indios, vigorously set about the destruction of Nahuatl cultural and religious materials, a goal not incongruous with his charge of protecting indios from Spanish excesses as well as their own blasphemous spiritual traditions.

d. The first school, opened in in Nezalhulpilli in I 523 , instructed one thousand sons of noble Mexican and Texcocan families in the Latin alphabet, songs, arts and crafts, agriculture, and Christianity. Other schools were subsequently founded throughout Mexico, primarily driven by Franciscan, Dominican, and Jesuit religious orders. 


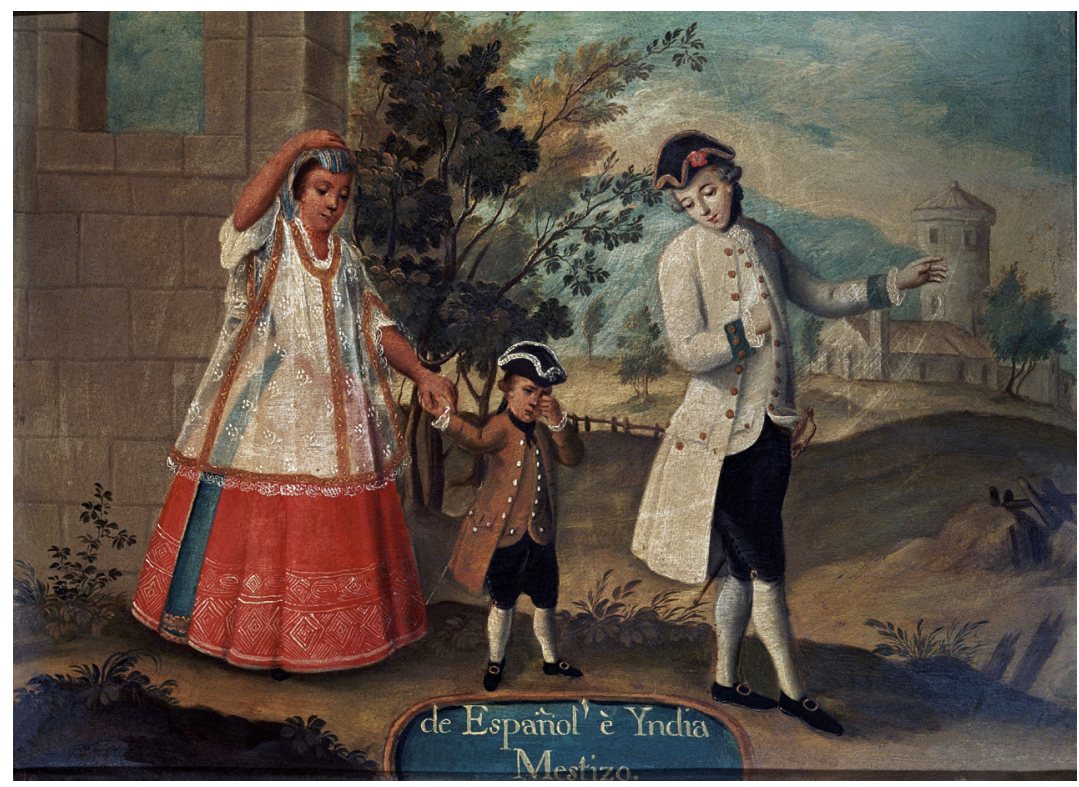

FIGURE 2. Mixity: Of Spain and India, eighteenth century. Copperplate painting (48 x $36 \mathrm{~cm})$. From Museo de America, Madrid. Photo by Album/Art Resource, NY.

connected Mexico City to San Juan Pueblo, in present-day New Mexico (United States). The Camino Real was the commercial lifeline of the colony, the route for silver extracted from the colony's mines to awaiting Spanish galleons in Veracruz and for linens, wines, tools, and other manufactured goods to the heartland of the territory. Transportation was initially carried out on the backs of indigenous slaves, but over time the Spanish shifted to oxen and mule trains, pulled by up to eighteen animals, which significantly increased the amount of cargo that could be carried. ${ }^{67}$

Precisely because roadways proved vital to extending the conquest into the northern regions of the colony, the diverse indigenous inhabitants, whom the Spanish referred to collectively as Chichimecas, launched frequent assaults on the wagon trains. ${ }^{68}$ The natives welcomed themselves to the raided linens, wines, and food, but they found little use for the silver that was the inspiration for Spanish encroachment into their lands. ${ }^{69}$ The Spanish efforts to quell the attacks came to be called the Chichimeca War, which lasted until I600. ${ }^{70}$ The eventual defeat of the Chichimecas did not ensure the security of mobility in New Spain, however. While banditry did not abound in colonial Mexico, as it 
would postindependence, population growth, unremitting unemployment, and the absence of political authority provided conditions ripe for its growth at the end of the seventeenth century. ${ }^{71}$

The existing legal body responsible for crime control in the colonythe Audiencia de Mexico and its Sala de Crimen (Criminal Court)—was powerless against the mobility and obscurity of bandits who preyed upon travelers. In response, the viceroy of New Spain took the radical step of founding a policing organization - the Tribuna de la Acordadaunder the authority of Miguel Velázquez de Lorea. Velázquez assumed the post only on the condition that he be empowered to not only apprehend suspects but also adjudicate cases and execute sentences. By the I780s, the Acordada was handling four-fifths of all criminal cases in the colony. Eventually, Velázquez's son, José, assumed command of the unit and founded a Guarda Mayor de Caminos (Elite Guard of Roadways) to root out roving bandits targeting travelers. The Guarda established guardhouses along major transit routes in the colony and escorted travelers as they passed. ${ }^{72}$ Through these autocratic measures, the Acordada was slowly able to take control of Mexico's roads and lessen the threat of banditry to the colony's commerce.

As these examples from Mexico's past demonstrate, royal authorities were intimately aware of the importance of "enrolling" ${ }^{73}$ material agents in their colonial project. The sistema de castas, pinturas de casta, and the construction and policing of roadways evidence how Spanish authorities crafted a framework to capture and cultivate the material dimensions of identification, communication, and mobility in New Spain to ensure the permanence of Spanish rule and protect it from the threats of foreign bodies, alien cultures, and banditry. And by doing so, central elements of the colonial state in Mexico-parochial schools and the Acordada, for instance—came into being.

\subsubsection{Building the State of Independent Mexico}

Following the expulsion of Spanish rule in I82I, Mexico faced a number of challenges to establishing itself as an independent country, including a reactionary European continent unsympathetic to revolutionary ideas following the defeat of Napoleon, the need to borrow heavily from other nations in order to bolster its military capacity against an expected Spanish invasion, a deeply entrenched Catholic Church unreceptive to the liberal ideas that inspired the independence movement, and an intense regionalism that prevented establishment of 
a strong national government. ${ }^{74}$ As a result, independence brought a long spell of political instability to Mexico, punctuated by a Spanish attempt to reconquer its former dependency from I82I to I835, the loss of half of its territory to its bellicose neighbor to the north following the Mexican-American War from I 846 to I 848 , a French-imposed monarch (Maximilian I) from I 864 to 1867 , and dozens of national administrations in between.

This instability notwithstanding, independence and the embrace of Enlightenment ideals exercised an influence on personal identification in Mexico. Independence from Spain did not bring racial harmony to the newly autonomous land. Indigenous peoples continued to be seen as an impediment to progress, a view now sanctioned by the scientific veneer of social Darwinism. ${ }^{75}$ But a notion of citizenship was developing in the country, which provided a broader basis for social integration than did Spanish rule. Both Benito Juárez, who served as president of Mexico for five terms, and Porfirio Díaz, who rose to prominence as Juárez's military chief, were of indigenous descent, and they and others in the ruling class saw mestizaje and the education of indios and the masses more generally as the path forward for the nation. ${ }^{76}$

Citizenship also implied voting rights. And independence from Spain initiated a period of experimentation with the democratic process that had profound impacts on personal identification and construction of the state. The first elections in postindependence Mexico operated under a "vague definition of suffrage that included no specific income or property restrictions." "77 Individual eligibility to vote was determined at local polling stations by election officials, a method of identification that could be exploited by those best able to mobilize the masses. In Mexico City, for instance, Masonic lodges vying for municipal power rounded up large numbers of people from poorer neighborhoods and supplied them with identical ballots with which to descend upon the city's eighteen polling places. ${ }^{78}$ With no means for timely verification of voter identity, such a massing of people overwhelmed the system's ability to distinguish individual voters and resulted in electoral successes for the lodges.

Such maneuvers produced fears among the ruling elite that democratic governance would result in a loss of power to groups deemed either morally or racially inferior. In response, more restrictive definitions of citizenship and more precise methods for identifying citizens were developed. Voting rights were restricted to males eighteen years old and above (or below if married), employed (but not as domestic 
servants), and with no criminal records, public debts, or physical or moral incapacities. ${ }^{79}$ This definition of citizenship not only excluded women but left criminal law as a key mechanism for excluding the poor and indigenous from voting. ${ }^{80}$ Unsurprisingly, criminality intersected with categories of class, race, gender, and sexuality, which served to exclude from the democratic project those groups historically marginalized in Mexican society. Identifying who was left to vote was handled by local election commissioners, who conducted censuses of their precincts to generate registries of eligible voters. Voter rolls were to be completed eight days prior to elections, and they were also to be made public so that the citizenry could petition for inclusion. Ballots were then mailed to voters, which served as a voter's credential and identity document on election day. ${ }^{81}$ In this way, democratic elections brought forth new methods of personal identification that are familiar to us today.

The political instability defining the first decades of Mexico's independence eventually gave rise to Porfirio Díaz, who held power in Mexico almost continuously from I 876 until the outbreak of the Mexican Revolution in I9ı0. Díaz's dictatorship, referred to as the Porfiriato, is generally read as a period in which strong militaristic rule forced political obedience upon society while erecting a framework for foreign investment and wealth extraction that exacerbated existing social inequalities and pushed the country to revolution. Critical to this period of political stability as well, however, was the development of modern systems of railway transportation and telegraph communication that allowed the central government to maintain ties to the state governors and local jefes politicos (political officials) it appointed to rule over Mexico's historically unruly regions (fig. 3$)^{8}$

These transportation and communication technologies helped bring forth key institutions and a rule of law that are characteristic of modernity. As Teresa Van Hoy notes in a fascinating social history of the railroad, whereas Mexican governments before the Porfiriato handled railway development in an ad hoc fashion, which left its fate to investors and developers, Díaz increased the government's hand through such offices as the Inspector of Railroads in 1877 and the Communication and Public Works Secretariat in $189 \mathrm{I} .{ }^{83}$ In addition, the regime passed legislation, such as a land expropriation law in I882 and the Federal Railroad Law of 1899 , to provide land rights to railroad developers.

While these legal rules and political bodies were meant to increase the power of the federal government to seize land from people, they actually helped residents strengthen and defend their land claims against 


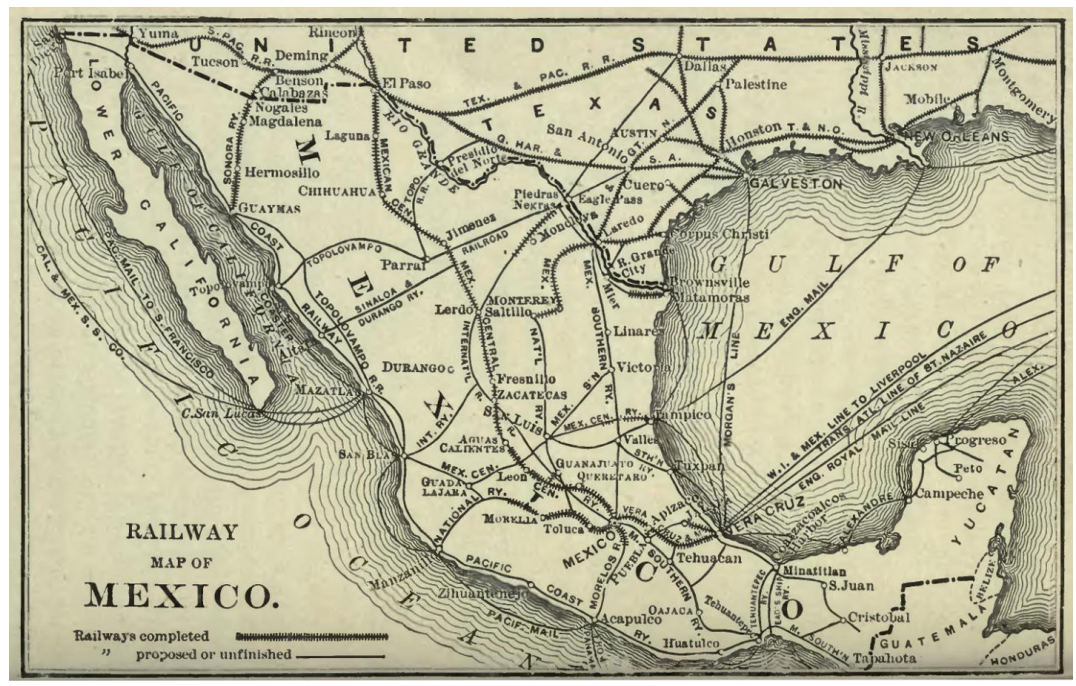

Figure 3. Map of railway expansion during the Porfiriato. From William Henry Bishop, Mexico, California, and Arizona (New York: Harper and Brothers, I900).

rail developers. ${ }^{{ }^{4}}$ This unforeseeable outcome reveals much about how political power works in practice. To carry out the land expropriation law, the federal government sent officials to local communities to oversee railroad construction and report expropriation cases back to the federal ministry. ${ }^{85}$ Once on site, however, officials encountered local authorities eager to use the railroad project to preserve their own power. ${ }^{86}$ In the push and pull between local and federal-level politics, a new legal space was created, where residents were able to "maneuver for better terms than the government itself intended." ${ }^{87}$ In the end, railroad development "inserted intermediaries into local power structures" and, in so doing, "linked local residents to federal authorities in ways that often channeled demands up more effectively than it imposed central authority down." ${ }^{88}$ As a result, a "rule of law" began to take root over the "personalism" that had defined politics in Mexico for centuries.

\subsubsection{Realizing the Revolutionary State}

The political stability of the Porfiriato did not last, as the economic inequality it engendered and the political abuses it relied on brought the country to rebellion. The Mexican Revolution represented a new era of civil strife and political chaos. And the near decade of intense 
fighting carried an enormous human toll and eviscerated the country's economy. Following the conflict, national leaders turned their attention to ensuring the peace by demobilizing armed groups, recuperating the country's agricultural production, and implanting revolutionary ideals across society. The general strategy for achieving these goals was crafted by Plutarco Elías Calles, president of Mexico from I924 to 1928, who founded the National Revolutionary Party (PNR) in I929, which would later become the Institutional Revolutionary Party (PRI) that held power until 2000. The corporatist structure of the PNR stabilized political and economic life by ensuring that political offices were determined by institutional forces rather than powerful individuals, corralling militant workers into state-sponsored unions and propagating revolutionary ideals through public schools and teachers who counteracted the power of the Catholic Church. The corporatist state model reached its apex under the administration of Lázaro Cárdenas (I934-40), who redistributed forty-five million acres of land from large landholders into communal holdings known as ejidos and nationalized the country's oil reserves in $19399^{90}$ In this way, somewhat ironically, "the formula of political centralism and dependent capitalist development" begun under Porfirio Díaz was perfected by the revolutionary leaders who had fought to erase his influence on national development. ${ }^{9 \mathrm{I}}$

Practically speaking, the state's plans to redistribute land into ejidos and reactivate the agricultural sector posed special challenges. Based in Mexico City, federal officials remained largely ignorant, if fascinated, by rural life in the Mexican hinterlands. Thus, to carry out land redistributions and better plan the rural economy, the federal government sent out teams of data collectors and surveyors in its I930 Agrarian Census to collect statistics and generate maps that would make this reality legible to the state. ${ }^{92}$

This was not Mexicans' first exposure to statistics. ${ }^{e}$ But the devastation of the revolution and emergence of statistics as a basic language of

e. The Mexica, for instance, tracked tribute paid by subjugated rivals (Ervin, "I930 Agrarian Census in Mexico," 539). The Spanish Crown, too, when looking to check the growing power of encomenderos (land-grant holders), instituted a tax that required "a counting of family heads," which functioned like a census (García Martinez, "Los años de la conquista," I90). The implementation and improvement of accounting practices were a core concern of the Bourbons, who came to power in Spain in I7I3 and sought to reverse centuries of apathetic management and tax collection in New Spain (MacLachlan, Criminal Justice in Eighteenth Century Mexico). 
politics provided extra impetus to authorities' data-collection efforts in the 1920 and $1930{ }^{93}{ }^{93}$ Communicating in the new language of statistics was not simply a matter of creating bureaucracies or sending young, idealist agronomists into the campo. Resistance met data collection at various points. Nonuniformity of measures was one. What constituted a "load," or carga, of wheat, for example, changed from locale to locale. And language made it worse. While statistics collectors found the "aztec-isms, or voices of Nahuatl origin, that live in the mouth of the Mexican farmer" to be problematic, Michoacán's "tarasc-isms," Yucatán's "mayanisms," and Oaxaca's "zapotec-isms" and "mixtecisms" compounded the confusion of measurements. One report claimed that the "lack of unified terminology" was "particularly prejudicial" to state efforts in the agricultural sector. ${ }^{94}$ What is more, the names of locales changed too, making it hard for officials to even locate places. Most vitally however, campesinos and large landholders resisted giving information to census takers, fearing the information would be used for the purposes of taxation or land appropriation. ${ }^{95}$

In response, the government and census workers worked to tie the new language of agrarian statistics to popular interests. Taking part in the census was "patriotic," "privacy" would be respected, "productivity" would increase and thereby benefit all, and "penalties" would be levied against those not participating. In addition, contests were held for best slogan to encourage Mexicans to participate in the census, balloons were distributed to schoolchildren with the word "Census" emblazoned on them, and teachers and state workers were enlisted to encourage those within their spheres of influence to take part. Despite these efforts, data collectors were ultimately left to negotiate the modernization project, trading information from farmers for the provision of water to an area. Still, these efforts helped bring into existence a modern state infrastructure to account for and communicate the material and social reality of Mexico.

With regard to mobility, the postrevolutionary state in Mexico sought to consolidate its power through the construction of roadways. Roads have a long history in Mexico, having served as the conduit not only for the extraction of mineral resources during the colonial era but also for the conduct of regional commerce during pre-Columbian times. ${ }^{96}$ Attention to road construction and maintenance diminished somewhat during the Porfiriato, as rail travel was prioritized. ${ }^{97}$ But with the growing importance of the automobile following the revolution, the federal government saw the construction of roadways as a way to tap 


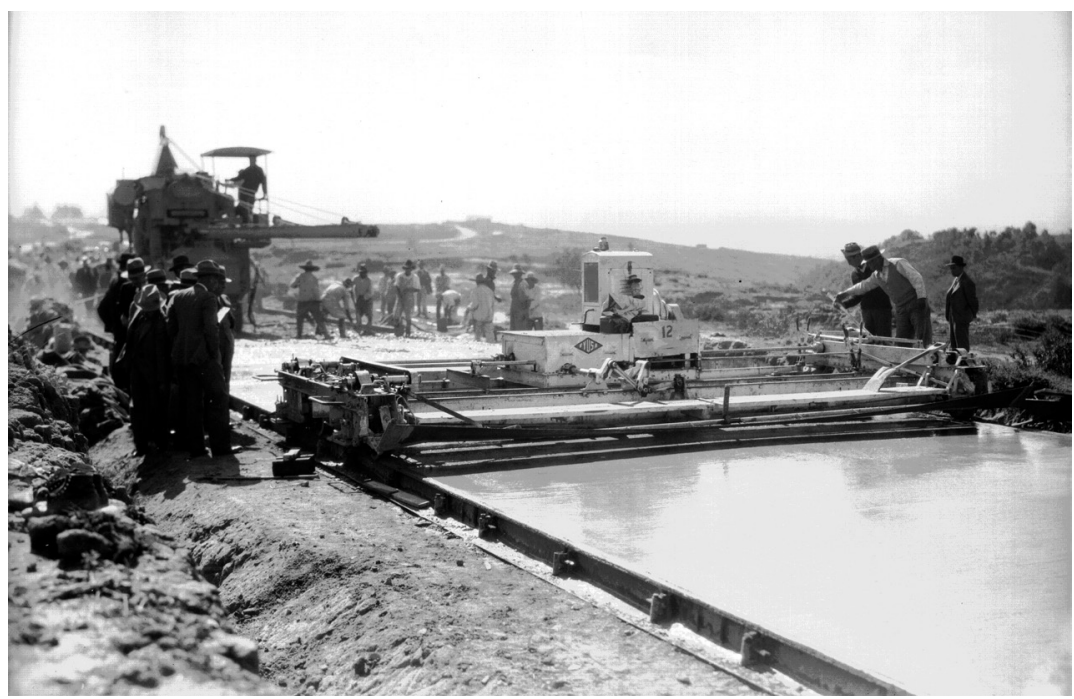

FIGURE 4. Workers operating machines in the construction of a roadway, c. I925. Photo from CONACULTA-INAH-MEX, reproduction authorized by the Instituto Nacional de Antropología e Historia.

the potential of this new form of mobility and better incorporate rural areas that remained outside the state's grasp (fig. 4). ${ }^{98}$

Initially, the postrevolutionary state focused on constructing new roads that would access areas untouched by railroads. ${ }^{99}$ A national highway system connecting Mexico's major cities and key economic areas soon followed. While foreign companies financed and constructed these new roadways at first, Plutarco Elías Calles, reflecting the nationalist inclinations of the postrevolutionary government, phased out their participation and founded the National Roads Commission in 1925 to oversee road construction and implemented a gasoline sales tax to finance the effort. ${ }^{\text {Ioo }}$ Around the same time, Calles nationalized all roads connecting the capital to key economic regions, state capitals, and neighboring municipalities. ${ }^{\text {IOI }}$ And to better attract the foreign currency of US tourists who had begun to frequent the country's beach resorts, the government prioritized construction of roadways that connected northern points of entry to tourist destinations. ${ }^{\text {Io }}$

By the middle of the twentieth century, the state's road construction strategy had evolved. With a growing Mexican automobile industry, the federal government dedicated 20 percent of all tax collected on the sale of vehicles assembled in the country to the construction of rural 
highways. ${ }^{\text {I03 }}$ The prodigious growth of Mexico's cities, meanwhile, brought traffic jams, a problem addressed through the construction of ring roads around metropolitan areas. ${ }^{\mathrm{I} 4}$

If the corporatist state model crafted by Calles and Cárdenas proved effective in creating an efficient highway system that integrated diverse regions of the country and supported Mexico's industrialization from the I940s to the I970s, it began to exhaust itself by the I980s. The highway system was aging. And the geography of international trade had shifted, as increased commerce with Asia and economic growth of the US West created the need for new highways in the western region of Mexico. Public funding, however, had become insufficient to finance and maintain new roads. In response, President Carlos Salinas de Gortari (1988-94) launched the National Highway Project in I989 to erect a new network of toll highways and bridges, which would be funded and operated by private companies. ${ }^{\text {. }}{ }^{2}$ Thus, roadways not only reflect authorities' efforts to harness automobility in modern Mexico, but they also trace the evolution of the postrevolutionary Mexican state from its corporatist origins in national integration and import substitution industrialization to its neoliberal embrace of global integration and export-oriented industrialization.

Finally, if elections in Mexico during the rule of the PNR/PRI were a sham, determined by the dedazo (fingermark), or personal preference, of the outgoing president rather than popular will, the hegemonic party held the democratic ideals of the revolution in high enough regard to at least hold elections. And elections occasioned the evolution of modes of personal identification for the purposes of determining voter eligibility. Following the revolution, the practice of mailing voters ballots that served as voter credentials and identity cards was discontinued. Instead, political parties prepared voter documents, which they sent to polling stations ahead of election day. This practice eventually gave way to the establishment of permanent voter rolls, which were compiled and verified at state and local levels. Following persistent charges of voter fraud, and reflecting the centralizing tendency of the postrevolutionary state, the federal government passed the I946 Federal Election Law, which shifted authority over voter rolls from local officials to the Federal Elections Commission. ${ }^{\text {I }}$

The Federal Election Law also defined requirements for voter cards. They were to be created in numerical succession, with no repetition, and in duplicate, with the original given to the voter and the copy remaining with the commission. Thus, voters came to be distinguished by a unique 
identifying number. In I95 I, the Federal Elections Commission further required voter cards to feature fingerprints as biometric proof of identity. ${ }^{\text {I07 }}$ In I987, additional elements were added to the card, including a security code and the imprinted signature of the general director of the National Registry of Voters.

These reforms did little to boost citizens' trust in the electoral system. The problem came to a head in the 1988 presidential election, when IBM computers responsible for counting votes famously crashed as opposition candidate Cuauhtémoc Cárdenas was leading the ruling party PRI-nominee Carlos Salinas. Salinas was ultimately named the winner. In the subsequent public outcry, the federal government created the Federal Electoral Institute (IFE), run by civilians and responsible for administering future elections. The IFE launched a nationwide census to verify voter rolls in I99I and began issuing a new voter card in I992, which included a photograph. As an individualized, accurate, and nonpartisan form of identity, the IFE voter card became the dominant form of identification in Mexico.

$* * *$

As these examples from the long arc of Mexican history show, the interest of authorities in controlling communications, identification, and mobility in Mexico is not new. Rather, such control is a constant goal of authorities, the pursuit of which gives shape to the state. The destruction of indigenous culture and imposition of the Spanish language in Mexico, the creation of the Acordada to police the Camino Real and other colonial roadways, the execution of surveys and use of ballots as identity documents during early independence, the establishment of the Inspector of Railroads and the Communication and Public Works Secretariat to oversee the construction of railways during the Porfiriato, the founding of public schools during the Calles and Cárdenas administrations, the launching of the National Highway Project by Carlos Salinas in 1989, and so on all represent efforts by state authorities to channel the collective agency of society, which in turn defined the shape of the state.

This aspect of state formation has been touched on by STS scholars exploring the boundaries of science, technology, and politics. ${ }^{\text {I09 }}$ As Sheila Jasanoff observes, "The dynamics of politics and power, like those of culture, seem impossible to tease apart from the broad currents of scientific and technological change. It is through systematic engagement with the natural world and the manufactured, physical 
environment that modern polities define and refine the meanings of citizenship and civic responsibility, the solidarities of nationhood and interest groups, the boundaries of the public and the private, the possibilities of freedom, and the necessity for control" "I0

But this historical perspective offers more than a view of state formation through authorities' efforts to control collective agency. It also reveals a dialectical dimension of state formation, whereby arrangements of the state that once proved satisfactory in administering society lose their efficacy as society evolves through the introduction of cultural and technological elements that alter how communication, identification, and mobility are accomplished. ${ }^{\mathrm{f}}$ The extraction of mineral wealth in New Spain through the construction of roadways and establishment of shipping lanes lent the territory a level of activity that the Crown ultimately could not handle. Nearly all of the seaports by the end of the sixteenth century were riddled with pirates and buccaneers, and the mercantile system was flouted by Spanish subjects on both sides of the Atlantic. ${ }^{\text {III }}$ Meanwhile, English, North American, and European traders pushed to open up new trade routes. ${ }^{\mathrm{II}}$ In the interior of the country, the continued construction of roadways rendered the guardhouses of the Guarda Mayor de Caminos of the Acordada ineffective. There was simply too much terrain for Spanish authorities to cover and too few resources with which to cover it. The advent of the railroad later provided the Porfiriato a novel manner for reordering the mobility of Mexican society and, in the process, developing the country's economic potential and the state's coercive capacity. But this mechanism ultimately proved incapable of quelling the societal unrest expressed in the Mexican Revolution and obsolete for constructing a postrevolutionary state in a world inhabited by the automobile. The national project of highway construction launched by the postrevolutionary governments of Elías Calles and Cárdenas proved effective in extending the reach of the central state to rural areas untouched by railroads and expanding trade with the United States. But the highway system began to lose its grip on mobility in Mexico once the corporatist state model experienced

f. I borrow this idea from STS scholars, who describe how scientific and technological production is forever introducing "actants" (Latour, Pandora's Hope) into society, nonhuman things with which humans can associate and amplify their capacity for action in the world. As a consequence, society is continually evolving in a state of "open-ended becoming" (Pickering, "New Ontologies," 4), where patterns of social interaction at one time do little to determine or predict patterns of social interaction or ways of being in the future. 
financial crises, the industrial geography of the world shifted, and tourists began visiting the country via airplanes rather than automobiles. In sum, while authorities' efforts to capture the social processes of mobility, communication, and identification help give form to the state, the "vibrancy" ${ }^{\mathrm{II} 3}$ of society is forever challenging the modes for ordering it.

\subsection{SURVEILLANCE TECHNOLOGIES AND REFORMING THE MEXICAN STATE}

These observations on the dialectical nature of state formation help set the scene for more fully understanding the significance of the RENAUT, CEDI, and REPUVE today. If attempts to manage communication, identification, and mobility are part and parcel of the state, then the launching of the RENAUT, CEDI, and REPUVE speaks to the failure of prevailing state infrastructure to effectively administer these aspects of collective agency. There has been considerable debate in recent years about the crisis facing the Mexican state. Noting its inability to control crime, observers in the international press and political arena have been quick to conclude that Mexico represents a "failed state." On September 9, 2010, US secretary of state Hillary Clinton courted controversy when she opined that the insecurity in Mexico was "looking more and more like Colombia looked 20 years ago, where the narco-traffickers controlled certain parts of the country," an opinion that US president Barack Obama had to quickly distance himself from. ${ }^{\mathrm{II}}$ Scholars, meanwhile, noting the historical symbiotic relationship between organized crime and political authorities, are more likely to conclude that the federal government in Mexico remains very much in charge. ${ }^{\mathrm{II} 5}$ The truth, as always, lies somewhere in the middle. The increasing levels of crime in Mexico evidence neither a failed state nor a state in control, but rather a state that is progressively losing its grip on society.

Society is continually evolving in conjunction with cultural and technological elements that modify the way communication, identification, and mobility are accomplished. In contemporary Mexico, the increasing number of mobile phones, computers, digital networks, automobiles, and so forth has changed the way people communicate, self-identify, and move and has diminished the state's capacity for control. Law enforcement is unable to track the telephone communications of kidnappers, corpses are buried in mass graves without being identified, and criminals are able to circulate freely through society given the lack of traffic regulation. In this way, these material agents have altered and 
amplified collective agency in Mexican society, causing it to overwhelm the state's capacity to harness it.

However, the difficulties facing the Mexican state today reflect more than a society vitalized by infusions of technology and materiality. They also reflect wider processes of change since the I980s. Some of this change involves external forces. For one, the global embrace of neoliberal political economy resulted in Mexico's abandoning the corporatist postrevolutionary state model that Presidents Calles and Cárdenas had forged in the I930s. Economic liberalization was initiated by President Miguel de la Madrid in the I980s and deepened with the North American Free Trade Agreement (NAFTA) in 1994. While economic liberalization has made some of Mexico's national industries more competitive, fostered trade with the United States and other countries, and led to a steady expansion of GDP ${ }^{\mathrm{II} 6}$ the poverty rate (as measured by income required for basic living expenses) has remained stuck at 50 percent of the population ${ }^{117}$ and the Mexican state has less ability to manage its effects.

Along with neoliberal political economy, the I980s and I990s saw Mexico and nearly all of Latin America undergo an era of democratization where competitive national elections were held for the first time in decades. In Mexico, the democratization process started at the local and regional levels, but it eventually resulted in the PRI losing the 2000 presidential contest. While this process has brought about free, competitive elections and increased civilian control over the political process, the resultant decentralization of power and weakening of clientelist relationships have diminished the power of the state to negotiate conflicts between competing social sectors. ${ }^{\mathrm{I} 18}$ And this has a clear relation to organized crime. Throughout modern Mexican history, the government turned a blind eye to, if demanding its wallets filled by, drug traffickers, so long as they kept to their own trafficking routes, or plazas, and did not engage in excessive violence. ${ }^{\text {II9 }}$ With democratic elections and the PRI's loss of power, organized crime syndicates have turned the tables and are now able to dictate terms to politicians in exchange for campaign financing and other incentives. ${ }^{\mathrm{I}}$

Also, globalization has transformed the economic and cultural landscape of Mexican society. The economic dimensions of globalization, which tie to neoliberal political economy, have resulted in increased foreign investment in sectors such as automobile and electronics production and have made information technologies such as personal computers and mobile phones more available. Connected to this, the 
opening of borders to facilitate international trade has created opportunities for international drug traffickers to take advantage of Mexico's immense border with the United States. The cultural dimensions of globalization have also had an impact on state control. At one time, the Mexican government used its monopoly over pulp to influence newspaper coverage in the country. ${ }^{\mathrm{I} I}$ In a digital, networked world, however, its ability to control popular opinion has shrunk. And the infusion of global culture through foreign movies, television shows, and the Internet has transformed cultural values in the world's second most populous Catholic country.

Together, these external pressures have transformed state power in Mexico. In a sense, the balance has shifted. Neoliberalism, democratization, and globalization have shrunk the size of the state and diminished its ability to provide for people's economic welfare, to shape popular opinion, and to manage crime, while strengthening the hand of other actors, such as multinational corporations, domestic media companies, and drug cartels.

In addition to these external pressures, the power of the Mexican state has been diminished by internal pressures or contradictions. One example of this is the redundancy of state infrastructure, which the Citizen Identity Card is intended to address. As the modern state developed, distinct bureaucratic institutions arose around the different functions thought to belong to government. The Federal Electoral Institute emerged to manage democratic elections. So too did the Tax Administration Service, to oversee the collection of taxes; and the National Defense Secretariat, to manage the national defense of the country. Each of these institutions, as well as others, possesses its own identity cards, which has resulted in a proliferation of identities in Mexican society. If a relatively minor inconvenience in people's everyday lives, the redundancy of identification runs counter to the state's interest in homogenization and centralization.

Another internal challenge is corruption. Corruption has a long history in Mexico. However, its valence is different than in the United States or the Global North. During Spanish Hapsburg rule, the Crown sold public offices to fund its military campaigns and state affairs in Europe. Thus, the path to political power for Mexicans in the colonial state was through the purchase of offices. In present-day Mexico, police are crippled by low salaries and sometimes required to purchase their own guns and gear, a situation that leaves them susceptible to 
corruption. ${ }^{\text {I22 }}$ Officers are expected to engage in rent-seeking activities, with the monies they procure sent up the chain of command to fulfill quotas established by their superiors. ${ }^{\text {I23 }}$ Despite its functional aspects, corruption ultimately diminishes the power of the state because proceeds from a traffic ticket negotiated at the site of offense go into the pockets of the police rather than the coffers of the state, and paperwork that would document the event is never generated. This allows suspect vehicles to escape the grasp of the formal legal order.

Finally, and building on the last point, much of the state's data on the people and things they look to govern are erroneous, which further decreases its administrative hold on society. In my interviews with REPUVE administrators, data errors were a common theme. As one federal official explained to me concerning vehicle registrations, "If I crossed the registration database with that of stolen vehicles using a license plate number, it would give me up to fifty registrations. Someone didn't put the plate number down correctly. So, it wasn't credible that from one license plate number I would have fifty stolen vehicles." This harkens back to the inaccurate data provided by campesinos and the nonuniform agricultural measures used in Mexico in the early twentieth century that rendered the I930 Agricultural Survey largely useless in imagining "the country's agricultural realities." ${ }^{\mathrm{I} 24}$ Without a common set of reliable information, state authorities find it difficult to carry out the task of governing.

Thus, the current crisis in governance in Mexico reflects a period of transformation in which the society that authorities seek to order has become increasingly dynamic while the state has atrophied. Globalization has helped transform Mexican society by introducing material artifacts (automobiles, computers, mobile phones, digital networks) that alter the way people communicate, self-identify, and move, while neoliberalism and democratization have forced the state to surrender the corporatist model that once controlled society. The Mexican state is not today failed. Nor is it in control. Rather, it finds itself in a situation where it must reinvent its capacity for governing in order to tame the tiger of Mexican society.

This, in the end, brings us back to surveillance technologies and their significance in Mexico today. The RENAUT, CEDI, and REPUVE are attempts by the Mexican state to adjust the mechanisms of power to fit the conditions it now faces. Confronted by a state infrastructure riddled with redundancy, corruption, and error, governmental authorities turn 
to incorruptible, precision technologies to reduce their reliance on overabundant, unprincipled, erring state employees. ${ }^{\mathrm{I} 25}$

The Citizen Identity Card responds to the redundancy of identity in Mexico by shepherding the different identities of Mexicans developed over time into a single document. The Spanish patterns of naming persons established during the conquest are inscribed onto the card. The enumerated assignment of identity to Mexicans through the Unique Population Registry Code is added to the card via a bar code. The biometric means for identifying people inherited from the voter card-the fingerprint and photograph-are supplemented by iris scans. As a technological device, the uniqueness of the CEDI lies not so much in its use of biometrics but in its amenability to diverse methods of identification.

With the REPUVE, meanwhile, human cops who rent-seek by overlooking traffic infractions are "displaced" "226 by teams of RFID stickers and scanners that have no motivation for financial gain. Ignacio Meza, a state official responsible for implementing the REPUVE in Zacatecas, alluded to this same point when I interviewed him. He remembered a time, "a few administrations ago," when the state operated a program that sought to put the vehicle roll in order.

The program was called Secure Transit. It was primarily a public safety program, but it also contained provisions allowing Finances to verify payments due. So, two Transit officials would go out, one person from Finances, and another person from the State Comptroller, who would serve as an observer to prevent acts of ill gains, abuse of authority, and so forth. This program allowed Transit authorities to monitor pollution emissions, tinted windows, seat belts, and so on.... The program helped elevate levels of compliance. But if every vehicle had a chip, we could start a new program of this type. With the scanner and chips, we could collect information on payments, and this would help the operation of such a program a lot.

It is worth noting that the older program required four people to operate, one to explicitly monitor the other officials. With the chips and scanners, another program could be launched, but without the need for so many human actors. Wondering how corruption would be affected by the program, I asked Meza what would happen with bribes. "Well," he replied, "we would be putting an end to that." Thus, by "delegating" to technological devices police work traditionally belonging to human law-enforcement officers, the state imagines itself more able to enforce vehicular regulations.

These considerations help mark out the true novelty of surveillance technologies in Mexico. The Mexican state's launching of the mobile 
phone registry, national identity card, and electronic automobile registry reveals an effort to reinvent itself in order to gain a handle on a rapidly changing society that is escaping its grasp. From this point of departure, what we need to consider in greater detail is how these programs might remake the state. Or, in other words, how are the programs designed to tame the tiger? 